\title{
Mango peel flour and potato peel flour as bioactive ingredients in the formulation of functional yogurt
}

\author{
María de Lourdes PÉREZ-CHABELA ${ }^{1 *}$ (D), Alejandra CEBOLLÓN-JUÁREZ¹, Elsa BOSQUEZ-MOLINA", \\ Alfonso TOTOSAUS ${ }^{2}$
}

\begin{abstract}
In recent years, agro-industrial by-products derived from processing and consumption mainly of fruits have become an important source of bioactive products, as fiber with or without prebiotic potential, and polyphenols with antioxidant activity against free radicals. In this research the chemical composition, including dietary fiber, besides polyphenols and TEAC, mean growth rate and mean duplication time, and prebiotic activity score of mango peel flour and potato peel flour were determined to evaluate the feasibility as functional ingredient in yogurt. Yogurt formulated with mango peel flour presented lower syneresis and higher viscosity during storage, as compared to yogurts with potato peel flour or control yogurt. Higher titratable acidity and lower $\mathrm{pH}$ was the reflect of the prebiotic capacity of both peel flours, with no detrimental effect on consumer acceptance. Mango peel flour and potato peel flour, with a prebiotic capacity potential due their dietary fiber content and polyphenols content, can be employed as prebiotic to improve probiotics colonization of gastrointestinal tract, with a concomitantly effect on host health.
\end{abstract}

Keywords: agro-industrial by-products; dietary fiber; polyphenols; prebiotics.

Practical Application: enhance nutritional value of yogurt with rich fiber and polyphenols ingredients.

\section{Introduction}

Consumption of dairy products has been increasing worldwide, mainly in developing countries and emerging economies (Gandhi \& Zhou, 2014; Lagrange et al., 2015). Fermented dairy foods as yogurt are an opportunity to counter deficiencies in nutrients intake as a good source of calcium, protein, and live bacteria, providing health benefits to the host. In the same way, dairy products as yogurt also contain considerable amounts of other macronutrients, vitamins, and minerals, being in general nutrientdense foods, where yogurt is as well a vehicle to fortification and a tool to improve nutrient deficiencies of vitamin D. Additionally, the nutritional value is especially high relative to cost (Gómez-Gallego et al., 2018). Yogurt consumption appears to be linked to healthier dietary patterns, adequate nutrient intake, and wellbeing lifestyles as well (Marette et al., 2017). Yogurt, as considered as a functional food, is clearly identified by urban Mexican consumers who identify this kind of foods with energy supplement, self-satisfaction, and body care, besides nutrition and economics (Rojas-Rivas et al., 2018). In this view, is important to increase consumption of foods with additional functions, like yogurt and other dairy products, to mitigate the spectrum of metabolic alterations associated to obesity to help the improvement of the dietary habits of the population and assist to fighting this worldwide public health problem (Tovar \& Herrera, 2017).

Separately, both yogurt and fruits are nutrient-dense and have a protective effect against diet-related diseases such as type 2 diabetes but combined in diet can be a good source of probiotics, prebiotics, high-quality protein, and important fatty acids (Fernández \& Marette, 2017). Food processing by-products are the sources for food processing industries and use of these by-products, directly or indirectly, for the manufacture of healthpromoting foods (Sharma et al., 2016). Agro-industry by-products rich in fiber and prebiotics can be added to processed foods like yogurt, not to replace fresh fruit consumption, provide a better source of these nutrients. In one hand, the relatively new interesting increasing trend to recover and utilize industrial by-products has an enormous potential in the agricultural and food processing industries, since the use of these byproducts contributes to the reduction of residues and wastes, reducing the environmental problem, being a low-cost source of dietary fiber, besides, that by-products contain an important content of bioactive phytochemicals (García-Amezquita et al., 2018). Since 2016 Mexico has become the $5^{\text {th }}$ mango producer, exporting around $20 \%$ of its production, this implies that $80 \%$ of the harvested mango (around 2 million tons of mango in 2018) was consumed locally (Secretaría de Agricultura, Ganadería, Desarrollo Rural, Pesca y Alimentación, 2019). In México City, potatoes were consumed as unpeeling potato chips processed by small business and consumed as snacks. During 2017 the average consumption of potato chips per person was around $3 \mathrm{~kg}$ (Kantar Worldpanel, 2018).

Flours made of fruits, cereals, and other vegetables edible parts are potential sources of prebiotic fibers and represent valuable economical alternatives for improving the nutritional 
value and functional quality of processed foods (Pérez-Chabela \& Hernández-Alcántara, 2018). The addition of these flours to dairy products as yogurt can be considered an option from economical and functional perspectives since these flours presents potential prebiotic effect promoting and enhancing the viability of probiotics impacting intrinsic quality parameters of the dairy foods (Santos et al., 2018). On the other hand, polyphenols, secondary plant metabolites, and their metabolized intermediaries or the end products, can modulate the activity and composition of the gut microbiota with a concomitantly effect on host health. Gastrointestinal microbiota is the most important reason for individual differences in polyphenol bioavailability, conversion, and absorption in humans, where interactions among different members of the gut microbiota are responsible for the short-chain fatty acid profile as the production of polyphenols degradation, and this selective stimulation of intestinal bacteria by polyphenols appears to be based on their potential to selectively inhibit the growth and/or activity of pathogens (Saulnier \& Blaut, 2015). Yogurt with probiotics combined with fruit peel flours leads us to the formulation of a symbiotic food. Symbiotic is a combination of probiotics and prebiotics that affects the host beneficially by improving the survival and colonization of selected live microbial strains in the gastrointestinal tract, causing the release of antibacterial substances such as bacteriocin (Fazilah et al., 2018). Combination of prebiotic (lactobionic acid) and prebiotic (L. casei) have been proposed to develop symbiotic dairy products (García et al., 2019). Lactic acid bacteria as L. acidophilus and L. plantarum are capable to degrade bisphenol in yogurt (Moghaddam et al., 2020). In fact, symbiotic yogurt presented an antihyperlipidemic effect on rabbits (Sarfraz et al., 2019).

The objective of this work was to determinate the potential of two agro-industrial by-products, potato peel flour, and mango peel flour, to be employed as a functional ingredient in yogurt, as fiber prebiotic (fermentative capacity and prebiotic index score) and antioxidant, besides to improve quality characteristics as serum release, viscosity, and acceptation.

\section{Material and methods}

\subsection{Agro-industrial coproducts flour elaboration}

Manila mango (Mangifera indica) peels were recovered from local fresh fruit processing establishments in Mexico City during mango season (from May to July 2019). White potato (Solanum tuberosum) peels were recollected during the same period.

Peels were dried in a Weston food dehydrator model 74-1001-w (Weston, Southern Pines) at $70^{\circ} \mathrm{C}$ for approximately $24-36 \mathrm{~h}$. Dried samples were ground in a grain mill and sieved consecutively in No. $100,80,50$, and 20 sieves to obtain a regular and homogeneous powder named flour (Chávez-Zepeda et al., 2009). Different lots were mixed to obtain a single batch. Mango peel and potato peel flours were stored in hermetic containers until use.

\subsection{Chemical composition, polyphenols determination, and antioxidant activity}

Chemical composition of peels flours was determined following AOAC Official Methods (Association of Official
Analytical Chemists, 1999) for moisture (Official Method 925.10), ashes (Official Method 942.05), total ethereal extract (Official Method 920.39), protein (Official Method 984.13, conversion factor 6.25), and total dietary fiber (Official Method 991.43). Total available carbohydrates were calculated as the difference of moisture, ashes, total protein, ethereal extract, and total dietary fiber. Total soluble carbohydrates were assessed by the Dubois et al. (1956) phenol-sulphuric method for total reducing sugars to formulate culture media for prebiotic activity score.

Polyphenols extraction was carried out by liquid-solid extraction. Mango peel flour (10 g) was placed in cellulose cartridges with $100 \mathrm{~mL}$ of acetone: water $(1: 1, \mathrm{vol} / \mathrm{vol})$ mixture (according to recommendations of Chantaro et al., 2008). Potato peel flour $(10 \mathrm{~g})$ was placed in cellulose cartridges with $100 \mathrm{~mL}$ of methanol (according to recommendations of Mohdaly et al., 2010). Cartridges were placed into Soxhlet equipment to distillate during $2 \mathrm{~h}$ to extract polyphenols.

Total polyphenol content was determined according to the methodology reported by Singlenton \& Rossi (1965). One mL of Folin-Ciocalteu reactive was added to $1 \mathrm{~mL}$ of sample and mixed with $8 \mathrm{~mL}$ of $0.7 \mathrm{M} \mathrm{Na}_{2} \mathrm{CO}_{3}$ for a final volume of $10 \mathrm{~mL}$. The mixture was allowed to stand $2 \mathrm{~h}$ at room temperature in the dark and absorbance was measured at $765 \mathrm{~nm}$ and extrapolated against a catechol standard curve (0 to $100 \mathrm{mg} / \mathrm{mL}$ ).

Antioxidant capacity was carried out according to the method described by Re et al. (1999). The extraction of polyphenols and related compounds was done by macerating $1 \mathrm{~g}$ of each flour in $100 \mathrm{~mL}$ of a methanol:water solution $(1: 2, \mathrm{v} / \mathrm{v})$ for $4 \mathrm{~h}$ at room temperature with magnetic stirring. Extracts were filtered with a Whatman No. 1 filter paper. $\mathrm{ABTS}^{+}$radical cation was generated by reacting $7 \mathrm{mM} \mathrm{2,2}$ '-Azino-bis (3-ethyl benzothiazoneline6-sulfinic acid) diammonium salt (ABTS) (Sigma Aldrich, St. Louis) and $2.45 \mathrm{mM}$ potassium persulfate after incubation at room temperature in the dark for $12 \mathrm{~h}$. The $\mathrm{ABTS}^{+}$solution was diluted in distilled water until an absorbance of $0.700 \pm 0.020$ at $734 \mathrm{~nm}$ was reached. A Trolox (6-hydroxy-2,5,7,8-tetramethylchroman2-carboxylic acid) solution $(20 \mu \mathrm{M})$ was prepared for the standard curve. $495 \mu \mathrm{L}$ of $\mathrm{ABTS}^{+}$solution was added to $5 \mu \mathrm{L}$ of sample and the reactive mixture was allowed to stand at room temperature for $6 \mathrm{~min}$ and the absorbance was immediately recorded at $734 \mathrm{~nm}$. Percentage of antioxidant activity was calculated by the following Equation 1:

Antioxidant activity $(\%)=\frac{\mathrm{Abs}_{\mathrm{Control}}-\mathrm{Abs}_{\text {Sample }}}{\mathrm{Abs}_{\mathrm{Control}}} \times 100$

Where $\mathrm{Abs}_{\text {Control }}$ is the absorbance of the control and $\mathrm{Abs}_{\text {Sample }}$ is the absorbance of the methanolic extract of fruit peel flours samples. Results were expressed in terms of Trolox equivalent antioxidant capacity (TEAC, Amol Trolox equivalents per $100 \mathrm{~g}$ dry sample).

\subsection{Bacterial growth and prebiotic activity score}

For bacterial growth, L. rhamnosus was reactivated in MRS broth at $37^{\circ} \mathrm{C}$ for $24 \mathrm{~h}$ until an optical density close to one $(\lambda=600 \mathrm{~nm})$ was obtained, equivalent to approximately 
$10^{7} \mathrm{CFU} / \mathrm{mL}$. E. coli was reactivated in biotriptase BX broth at $35^{\circ} \mathrm{C}$ for $18 \mathrm{~h}$ obtaining a similar optical density. Fermentations were performed by adapting the methodology described by Bustamante et al. (2006). The culture media were formulated by employing mango peel flour or potato peel flour as a carbon source to evaluate their effect on the growth of $L$ rhamnosus. The culture media were composed of $0.5 \%$ casein peptone $(\mathrm{w} / \mathrm{v})$, $0.3 \%$ yeast extract and carbon source $(1.0 \mathrm{w} / \mathrm{v}$ of peel flour). Glucose was employed as control and the amount of added peel flour was calculated according to the total soluble carbohydrates (total reducing sugars) to add the same amount of carbon source. Strain $\left(10 \mathrm{~mL}\right.$ with $\left.10^{7} \mathrm{CFU} / \mathrm{mL}\right)$ was inoculated into $90 \mathrm{~mL}$ of the different culture media in a serological flask $(100 \mathrm{~mL})$ and incubated at $37^{\circ} \mathrm{C}$.

Fermentations were monitored for $10 \mathrm{~h}$, sampling each hour to determine the viable count to determinate bacterial growth performance was by standard plate count in their respective culture medium, making the pertinent dilutions, incubating at $37^{\circ} \mathrm{C}$ for $24 \mathrm{~h}$ under anaerobic conditions. Mean growth rate constant $k$ (Equation 2) and mean duplication time $g$ (Equation 3 ) were determined according to Willey et al. (2008) equations, as follows:

$\mathrm{k}=\frac{\log \mathrm{N}_{10}-\log \mathrm{N}_{0}}{\log 2 \times 10}$

$\mathrm{g}=\frac{1}{\mathrm{k}}$

Where $N_{10}=\mathrm{CFU} / \mathrm{mL}$ at the end of fermentation $(10 \mathrm{~h})$ and $N_{0}=\mathrm{CFU} / \mathrm{mL}$ at the start of fermentation $(0 \mathrm{~h})$.

Prebiotic activity score of both mange peel flour and potato peel flour were determined according to methodology described by Huebner et al. (2007). Fermentations were monitored during $8 \mathrm{~h}$, sampling each hour to determine the viable count of probiotic L. rhamnosus and E. coli at 0 and 8 h. Prebiotic activity score was determined as the relationship considering the growth of each bacteria during fermentation employing mango peel flour or potato peel flour as prebiotic flour among bacterial growth employing glucose as carbon source, according to the Equation 4:

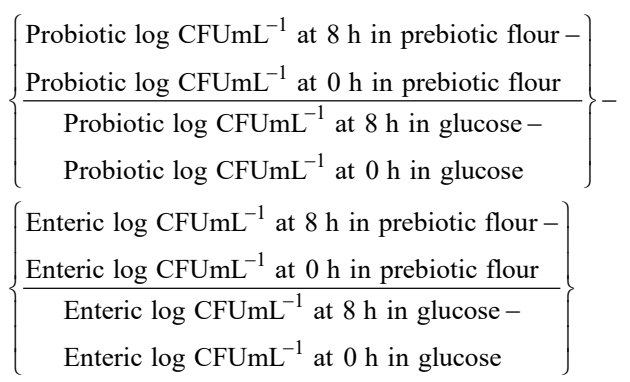

\subsection{Yogurt elaboration and properties}

Yogurt was elaborated following the methodology reported by Sendra et al. (2010). Fibers were dispersed (2\% mango peel flour or $2 \%$ potato peel flour) in $1 \mathrm{~L}$ of rehydrated skim milk $(10 \% \mathrm{w} / \mathrm{v})$. Pasteurization was made in a water bath at $80^{\circ} \mathrm{C}$ for $30 \mathrm{~min}$ to cool down in an ice bath to $43^{\circ} \mathrm{C}$ before inoculation of
$30 \%$ of plain yogurt as a starter culture (containing Streptococcus thermophilus and Lactobacillus delbrueckii subsp. bulgaricus), dispersing gently. Inoculated milk samples were incubated at $40{ }^{\circ} \mathrm{C}$ for $24 \mathrm{~h}$ before storage at $4{ }^{\circ} \mathrm{C}$ for 3 weeks.

The effect of added peels flour on the inoculated lactic acid bacteria development inoculated in yogurt was determined by measuring syneresis, acid production, $\mathrm{pH}$, and apparent viscosity. Syneresis was determined according to Díaz-Jiménez et al. (2004) methodology. $5 \mathrm{~g}$ of yogurt was centrifuged at $2,000 \times \mathrm{g}$ during $20 \mathrm{~min}$ to separate yogurt serum, reporting the percent of syneresis as the rate of the serum weight and yogurt weight sample. Apparent viscosity was determined with a Brookfield RVT viscometer (Brookfield Laboratories, Middleboro) at $60 \mathrm{rpm}$ after $60 \mathrm{~s}$ with a spindle \# 02 in

Titratable acidity and $\mathrm{pH}$ in yogurt samples were determined with $20 \mathrm{~mL}$ of yogurt diluted with $40 \mathrm{~mL}$ of distilled water, plus six drops of phenolphthalein as an indicator solution. Samples were titrating with $\mathrm{NaOH}$ standard solution $(0.1 \mathrm{~N})$ while stirring constantly until a faint pink color appearance. Titration continues until a persistent pink coloration, to report titratable acidity in $\mathrm{g}$ of lactic acid per liter. The $\mathrm{pH}$ was measured directly to yogurt samples with a Beckman 500 Benchtop Meter (Beckman Coulter, Fullerton).

\subsection{Yogurt sensory acceptation}

Acceptability of yogurt formulated with potato peel flour or mango peel flour was rated employing a $10 \mathrm{~cm}$ structured graphical hedonic scale marked with a far-left anchor of 'extremely unacceptable' and far-right anchor 'extremely acceptable' (Clark $\&$ Johnson, 2002). A total of 50 participants (28 males and 22 females, in an age ranged from 20 to 40) recruited from faculty members and students, with a taste for "healthy" products consumption and habitual yoghurt consumers recruited to evaluate the samples (Chetachukwu et al., 2019).

projective methods based in consumer perception. No sensory training was provided with prior evaluation sessions. Acceptation test was conducted under natural light illumination. Two samples (approximately 20-25 g) of control yogurt and yogurt formulated with mango peel flour or potato peel flour, elaborated a week before, were presented to panelists identifying the sample with 3-digit random numbers. Persons were asked to rate, according to their personal appreciation, a position anywhere along the scale to rate appearance, color, flavor, and odor (related to sweet taste, creaminess, and consistency, reported as most important attributes for the acceptance of consumers' acceptance of functional yogurts, according to da Costa et al., 2020), during and after tasting the different samples, marking a position anywhere along the scale to match their perception. Ratings were converted to a numerical score based on the distance in $\mathrm{mm}$ from the far-left anchor of the scale.

\subsection{Experimental design and data analysis}

A one-factor with three levels (mango peel flour, potato peel flour, or glucose as carbon source) was employed to determinate the effect of carbon source on the mean growth rate, mean duplication time and prebiotic activity score, using the PROC ANOVA procedure of the SAS statistical software 
v. 9.3 (SAS Institute, Cary). The significant difference among means was determined by Duncan's means test $(P=0.05)$ in the same software.

In order to determine the effect of mango peel flour or potato peel flour such as a functional ingredient in yogurt during storage, the proposed model was the following Equation 5:

$y i j=\mu+\alpha i+\beta j+\epsilon i j$

Where yij represents the yogurt syneresis, apparent viscosity, titratable acidity and $\mathrm{pH}$ for the ith treatment at the jth day of storage; $\alpha i$ and $\beta j$ are the main effects of treatment and storage time; $\in$ ij represents the residual error terms, assumed to be normally distributed, with zero mean and variance $\sigma^{2}$ (Der \& Everitt, 2008). Data analysis was carried out using the SAS statistical software PROC ANOVA procedure. the significant difference among means was determined by Duncan's means test $(\mathrm{P}=0.05)$ in the same software.

Acceptance results were analyzed using a paired t-test with the PROC TTEST employing PAIRED statement and alpha $=0.05$ ( $95 \%$ confidence interval) in the same statistical software.

\section{Results and discussion}

Results of the peels flours chemical composition, polyphenols content, and antioxidant activity are listed in Table 1. In general, potato peel flour samples presented higher content of moisture, ashes, ethereal extract, protein, and total carbohydrates, as compared to the mango peel flour samples. Nonetheless, dietary fiber was higher ( 3 times fold) in mango peel flour than in potato peel flour. In the same manner, polyphenols content was higher for mango peel flour samples, with a concomitantly higher antioxidant capacity as well (twice for mango). Despite to present the half of the mango peel flour TEAC value, potato peel waste presented acceptable in vitro antioxidant potency and can be effectively employed as an ingredient in functional foods to alleviate oxidative stress (Singh \& Rajini, 2004). Also, mango peel contains a great number of polyphenolic compounds, as phenolic acids, and flavonoids, indicating that mango peel is as well an excellent source of antioxidants (Peng et al., 2019), with high dietary fiber content (Patil \& Bharati, 2019). It has been reported that the antioxidant of mango peel bioactive compounds capacity remained constant even when was applied into edible film coating in apple slices during storage (close to $145 \mathrm{mg}$ of Trolox/100 g after 12 days of storage in $2 \%$ of mange peel coating) (Rojas-Bravo et al., 2019). Differences in the composition are inherent to the botanical origin, besides changes during ripening of climacteric fruits, as mango (Palafox-Carlos et al., 2012).

When mango peel flour or potato peel flour was employed as a carbon source, their performance was satisfactory, as compared to glucose. In this respect, both mean growth rate constant and mean duplication time were significantly $(\mathrm{P}<0.05)$ higher for mango peel flour; nonetheless, the prebiotic activity score was significantly $(\mathrm{P}<0.05)$ higher for potato peel flour (Table 2). Mango peel flour with more dietary fiber and total soluble sugars allowed a faster growth of the lactic acid bacteria; but during the prebiotic activity score evaluation, potato peel
Table 1. Chemical composition, polyphenols and antioxidant activity of mango peel flour and potato peel flour.

\begin{tabular}{|c|c|c|}
\hline Sample & Mango peel flour & Potato peel flour \\
\hline Moisture (\%) & $4.41 \pm 0.36$ & $4.95 \pm 0.17$ \\
\hline Ashes (\%) & $4.99 \pm 0.05$ & $8.07 \pm 0.11$ \\
\hline Ethereal extract (\%) & $8.04 \pm 0.91$ & $13.43 \pm 0.62$ \\
\hline Protein (\%) & $9.0 \pm 1.23$ & $14.41 \pm 0.82$ \\
\hline Dietary fiber (\%) & $35.41 \pm 0.58$ & $15.02 \pm 0.58$ \\
\hline $\begin{array}{l}\text { Total soluble } \\
\text { carbohydrates (\%) }\end{array}$ & $40.08 \pm 0.77$ & $52.80 \pm 1.18$ \\
\hline $\begin{array}{l}\text { Polyphenols } \\
\text { (mg/100 g sample) }\end{array}$ & $3705 \pm 9.89$ & $940 \pm 0.99$ \\
\hline $\begin{array}{l}\text { TEAC ( } \mu \text { m equivalents } \\
\text { of Trolox/g sample) }\end{array}$ & $1525.75 \pm 0.35$ & $751.25 \pm 0.71$ \\
\hline
\end{tabular}

Table 2. Mean growth rate constant ( $k$ ), mean duplication time (g) and prebiotic activity score for mango peel flour and potato peel flour.

\begin{tabular}{lccc}
\hline Carbon source & $\begin{array}{c}\text { Mean growth } \\
\text { rate constant } \\
\left(\mathrm{h}^{-1}\right)\end{array}$ & $\begin{array}{c}\text { Mean } \\
\text { duplication time } \\
(\mathrm{h})\end{array}$ & $\begin{array}{c}\text { Prebiotic } \\
\text { activity score }\end{array}$ \\
\hline Glucose & $1.66 \pm 0.01 \mathrm{c}$ & $0.57 \pm 0.011 \mathrm{c}$ & \\
Mango peel flour & $1.72 \pm 0.02 \mathrm{a}$ & $0.62 \pm 0.019 \mathrm{a}$ & 0.25 \\
Potato peel flour & $1.70 \pm 0.03 \mathrm{~b}$ & $0.60 \pm 0.015 \mathrm{~b}$ & 0.74 \\
\hline a, b, c means with same letter in same column are not significantly $(\mathrm{P}>0.05)$ different.
\end{tabular}

flour prebiotic components were more specifically consumed by the lactic acid bacteria, presenting better prebiotic capacity. Chemical composition of peel flours determines their ability to be fermentable (total soluble/reducing sugars) and serve as prebiotics (oligosaccharides and higher structures besides non-digestible compounds). Different structures of the different structures of carbon sources present had as consequence different and selective microbial growth (Cardelle-Cobas et al., 2011). Mango peel flour and potato peel flour have positive prebiotic activity index scores, reflecting the ability of these substrates to support the growth of probiotic microorganisms compared with other microorganisms, as pathogens, in contrast to a nonprebiotic substrate (glucose) (Huebner et al., 2007).

In symbiotic foods formulation is important the presence of fermentable sugars and probiotics. By its nature, phytochemicals recognized for their health potentials include phenolic compounds and non-digestible carbohydrate compounds that can be employed in the formulation of functional foods, serving as practical and economic sources of antioxidant (Fazilah et al., 2018). There is evidence that polyphenols, which are not strictly defined as fibers, might be classified as prebiotics in the future due to their health benefits and gut microbiota change in response to these bioactive compounds (Saulnier \& Blaut, 2015). At this respect, Bialonska et al. (2010) reported that pomegranate byproduct phenolic compounds (as gallic acid and ellagic acid) and oligomers improved the growth of probiotic bacteria, whereas other polyphenols (as punicalagins, the major pomegranate polyphenol) did not affect the growth of bacteria or production of short chains fatty acids. For example, Jerusalem artichoke tuber flour (Helianthus tuberosus L.) has been proposed as a 
new prebiotic source for the development of functional yogurt (Ribeiro et al., 2019).

\subsection{Yogurt evaluation}

The incorporation of mango peel flour or potato peel flour as functional ingredients modified the properties of yogurt. Yogurt syneresis was significantly $(\mathrm{P}<0.05)$ lower in samples containing mango peel flour, and the higher syneresis values were observed in control samples with no added fruit peel flour. Syneresis significantly $(\mathrm{P}<0.05)$ decreased with storage time Yogurt apparent viscosity was significantly $(\mathrm{P}<0.05)$ higher in samples formulated with mango peel flour, and the lower viscosity values were observed in control samples. Yogurt viscosity increased significantly $(\mathrm{P}<0.05)$ with storage time. Yogurt control samples presented the lower titratable acidity values, whereas the significantly $(\mathrm{P}<0.05)$ higher values were observed in mango peel flour samples. Titratable acidity increased significantly $(\mathrm{P}<0.05)$ during storage time until 21 days of storage. The $\mathrm{pH}$ value of yogurt control samples was the lower one since yogurt formulated with mango peel flour resulted in the significantly $(\mathrm{P}<0.05)$ higher $\mathrm{pH}$ values. The $\mathrm{pH}$ of yogurts increased significantly $(\mathrm{P}<0.05)$ during storage until the 21 days of storage (Table 3). Other ingredients as pine honey had been employed to reduce syneresis, and producers can use it in yogurt formulations decreasing serum separation (Coskun \& Karabulut Dirican, 2019).

Not all the fruit peels affect yogurt fermentation. At this respect, whereas no difference in yogurt $\mathrm{pH}$ with papaya peel flour was detected during storage (Manzoor et al., 2019), titratable acidity in yogurts containing passion fruit peel powder was significantly higher than in their respective control, behavior expected by the homolactic metabolism of the lactic acid bacteria (do Espírito Santo et al., 2012). This is the reason why determinate the prebiotic activity score is important. Although the concomitant effect of mango peel flour on the growth of lactic acid bacteria in yogurt during storage, reflected in lower $\mathrm{pH}$ due lactic acid produced, the syneresis in samples containing this agro-industrial co-product was lower besides present a higher apparent viscosity. The continuous growth of lactic acid bacteria that produce lactic acid through storage is responsible for the decrease in $\mathrm{pH}$, increasing the tendency to exhibit syneresis, affecting yogurt structure. However, mango peel flour compensates the putative detrimental effect of acidification during storage by two possible mechanisms, one the high fiber content that retained moisture, and the other, the polyphenol content that interacts with proteins. On one hand, fruit peels flour increased yogurt viscosity and increased water retention, decreasing syneresis during storage time (Vieira et al., 2015; Manzoor et al., 2019). On the other hand, Dönmez et al. (2017) reported that the addition of green coffee powder and green tea powder increased the total phenolic content enhancing the retention of more serum phase in yogurt, decreasing syneresis during storage. This is explained by the protein-polyphenol interaction that resulted in a haze of active protein that has a fixed number of polyphenol binding sites, and proteins with higher percentages of proline tend to form more haze (Siebert et al., 1996). Since proline was one of the dominant among non-essential amino acids in milk caseins (Rafiq et al., 2016), this polyphenols-protein interaction to decrease yogurt syneresis is expected.

In the sensory acceptation test (Table 4), for yogurt color of samples containing potato peel flour or mango peel flour obtained significantly $(\mathrm{P}<0.05)$ lower acceptation scores than the control sample. In the yogurt flavor, there was not significantly $(\mathrm{P}>0.05)$ difference between samples containing peel flour and control acceptance. Samples with potato peel flour were significantly $(\mathrm{P}<0.05)$ less accepted than control samples, whereas samples with mango peel flour obtained not significantly $(\mathrm{P}>0.05)$ different scores than control samples. Finally, in yogurt general appearance, potato peel flour containing samples

Table 3. Syneresis, apparent viscosity, titratable acidity and $\mathrm{pH}$ of yogurt added with mango peel flour or potato peel flour during storage.

\begin{tabular}{|c|c|c|c|c|}
\hline \multirow{2}{*}{ Treatment } & \multicolumn{4}{|c|}{ Storage time (days) } \\
\hline & 1 & 7 & 14 & 21 \\
\hline \multicolumn{5}{|l|}{ Syneresis (\%) } \\
\hline Control & $69.4 \pm 1.46 \mathrm{a}, \mathrm{A}$ & $68.8 \pm 1.51 \mathrm{a}, \mathrm{B}$ & $67.9 \pm 3.36 \mathrm{a}, \mathrm{C}$ & $66.5 \pm 1.08 \mathrm{a}, \mathrm{D}$ \\
\hline Potato peel flour & $68.1 \pm 2.00 \mathrm{~b}, \mathrm{~A}$ & $67.4 \pm 2.52 \mathrm{~b}, \mathrm{~B}$ & $67.2 \pm 3.19 \mathrm{~b}, \mathrm{C}$ & $65.9 \pm 1.47 \mathrm{~b}, \mathrm{D}$ \\
\hline Mango peel flour & $68.7 \pm 1.00 \mathrm{c}, \mathrm{A}$ & $68.2 \pm 0.33 c, B$ & $67.6 \pm 0.00 c, C$ & $65.3 \pm 2.26 c, D$ \\
\hline \multicolumn{5}{|c|}{ Apparent viscosity (Poises) } \\
\hline Control & $100.5 \pm 0.15$ с. $\mathrm{C}$ & $105.2 \pm 0.08 c, B$ & $112.4 \pm 0.29 c, B$ & $136.4 \pm 0.29 c, A$ \\
\hline Potato peel flour & $108.3 \pm 0.29 b, C$ & $132.2 \pm 0.42 \mathrm{~b}, \mathrm{~B}$ & $148.3 \pm 0.29$ b. B & $154.1 \pm 0.04 \mathrm{~b}, \mathrm{~A}$ \\
\hline Mango peel flour & $136.0 \pm 0.04 \mathrm{a}, \mathrm{C}$ & $163.4 \pm 0.21 \mathrm{a}, \mathrm{B}$ & $174.1 \pm 0.08 \mathrm{a}, \mathrm{B}$ & $180.2 \pm 0.71 \mathrm{a}, \mathrm{A}$ \\
\hline \multicolumn{5}{|c|}{ Titratable acidity (lactic acid g/L) } \\
\hline Control & $0.51 \pm 0.00 \mathrm{c}, \mathrm{A}$ & $0.70 \pm 0.00 \mathrm{c}, \mathrm{B}$ & $0.72 \pm 0.01 \mathrm{c}, \mathrm{C}$ & $0.91 \pm 0.01 \mathrm{c}, \mathrm{D}$ \\
\hline Potato peel flour & $0.80 \pm 0.02 \mathrm{~b}, \mathrm{~A}$ & $0.81 \pm 0.00 \mathrm{~b}, \mathrm{~B}$ & $0.93 \pm 0.01 \mathrm{~b}, \mathrm{C}$ & $1.05 \pm 0.02 \mathrm{~b}, \mathrm{D}$ \\
\hline Mango peel flour & $0.90 \pm 0.03 \mathrm{a}, \mathrm{A}$ & $1.01 \pm 0.02 \mathrm{a}, \mathrm{B}$ & $1.15 \pm 0.02 \mathrm{a}, \mathrm{C}$ & $1.23 \pm 0.03 \mathrm{a}, \mathrm{D}$ \\
\hline \multicolumn{5}{|l|}{$\mathrm{pH}$} \\
\hline Control & $5.00 \pm 0.58 \mathrm{c}, \mathrm{A}$ & $5.10 \pm 0.04 c, B$ & $5.10 \pm 0.16 c, C$ & $4.70 \pm 0.08 c, D$ \\
\hline Potato peel flour & $5.10 \pm 0.58 \mathrm{~b}, \mathrm{~A}$ & $5.00 \pm 0.29 \mathrm{~b}, \mathrm{~B}$ & $4.80 \pm 0.29 b, C$ & $4.80 \pm 0.16 b, D$ \\
\hline Mango peel flour & $5.30 \pm 0.16 \mathrm{a}, \mathrm{A}$ & $5.00 \pm 0.16 \mathrm{a}, \mathrm{B}$ & $4.90 \pm 0.25 \mathrm{a}, \mathrm{C}$ & $4.85 \pm 0.04 \mathrm{a}, \mathrm{D}$ \\
\hline
\end{tabular}

a, b, c Means with same letter in same column are not significantly $(\mathrm{P}>0.05)$ different for treatment; $\mathrm{A}, \mathrm{B}, \mathrm{C}, \mathrm{D}$ Means with same letter in same row are not significantly $(\mathrm{P}>0.05)$ different for storage time. 
Table 4. Sensory acceptability rating for yogurt formulated with potato peel flour or mango peel flour $(n=50)$.

\begin{tabular}{|c|c|c|c|c|c|}
\hline \multirow{2}{*}{ Attribute/Treatment } & \multirow{2}{*}{$\begin{array}{c}\text { Mean score } \\
\text { (with peel flour) }\end{array}$} & \multirow{2}{*}{ Means score (control) } & \multirow{2}{*}{$\begin{array}{l}\text { Mean difference } \\
\text { (peel flour-control) }\end{array}$} & \multicolumn{2}{|c|}{ 95\% CI interval for difference } \\
\hline & & & & lower & Upper \\
\hline \multicolumn{6}{|l|}{ Color } \\
\hline Potato peel flour & 3.10 & 3.60 & $-0.50^{*}$ & 1.001 & 1.494 \\
\hline \multicolumn{6}{|l|}{ Flavor } \\
\hline Potato peel flour & 2.14 & 2.44 & -0.30 & 1.016 & 1.516 \\
\hline Potato peel flour & 3.22 & 3.74 & $-0.52^{*}$ & 0.870 & 1.287 \\
\hline Mango peel flour & 3.44 & 3.74 & -0.30 & 0.965 & 1.429 \\
\hline \multicolumn{6}{|l|}{ General appearance } \\
\hline Potato peel flour & 2.96 & 3.38 & $-0.42^{*}$ & 1.133 & 1.691 \\
\hline Mango peel flour & 3.04 & 3.38 & -0.08 & 1.064 & 0.587 \\
\hline
\end{tabular}

${ }^{*}$ Value for peel flour was significant $(\mathrm{P}<0.05)$ different from equivalent control. $\mathrm{CI}=$ Confidence interval.

were significantly $(\mathrm{P}<0.05)$ less accepted than control samples, whereas there was not significantly $(\mathrm{P}>0.05)$ difference between mango peel flour samples and control samples. Agro-industrial by-products had been used to improve sensory acceptation of yogurt, as green olive powder (Cho et al., 2017) or papaya peel powder (Manzoor et al., 2019). Although all the scores values in this research were below the middle point (nor like or dislike), the scores for fruit peel containing yogurts were close to the scores of control yogurt samples, with a slight preference to mango peel containing yogurt. Mango peel fruit or potato peel fruit resulted in minor changes in sensory attributes. This means that it can be added to plain non-flavor yogurt or in flavored yogurt with fruit. Yogurt fruit preparation had to set a series of specifications based on the finished yogurt characteristics with good and normal character and color, flavor and odor, besides the particular manufacturer specifications and ingredients (fruit, fruit puree, and juice, sweetener, stabilizers, acidifying or buffering agent, color, flavor or preservative) (O'Rell \& Chandan, 2013), where the fruit peel or fiber content is negligible.

\section{Conclusion}

Agro-industrial by-products have been demonstrated their feasibility as functional ingredient for most processed foods. It has been demonstrated that discarded fruit peels are a source of dietary fiber that can serve as prebiotics, besides the content of the bioactive substances, like polyphenols with an antioxidant activity against free radicals. In this view, the use of fruit or vegetable peel flours as a cheap source of functional ingredients is a viable alternative to enhance the nutritional composition of foods, like yogurt. In fermented dairy products, mango peel flour and potato peel flour, with a prebiotic capacity potential due their dietary fiber content and polyphenols content, can be employed as prebiotic to improve the development of probiotic strains in gastrointestinal tract, with the healthy benefits that this kind of strains impart in gut microbiome. If yogurts are made with probiotic strains, a symbiotic yogurt can be elaborated. The chemical composition of mango peel fruit and potato peel fruit also enhance the yogurt properties, since the fiber retarded serum release produced by acidification, and polyphenols interaction enhance acid-gel yogurt network, improving apparent viscosity.
The use of relatively a low amount of mango peel flour or potato peel flour had no major detrimental effect on yogurt sensory attributes.

\section{References}

Association of Official Analytical Chemists - AOAC. (1999). Official methods of analysis of the Association of Official Analytical Chemists (16th ed.). Washington: AOAC.

Bialonska, D., Ramnani, P., Kasimsetty, S. G., Muntha, K. R., Gibson, G. R., \& Ferreira, D. (2010). The influence of pomegranate by-product and punicalagins on selected groups of human intestinal microbiota. International Journal of Food Microbiology, 140(2-3), 175-182. http:// dx.doi.org/10.1016/j.ijfoodmicro.2010.03.038. PMid:20452076.

Bustamante, P., Mayorga, L., Ramírez, H., Martínez, P., Barranco, E., \& Azaola, A. (2006). Evaluación microbiológica de compuestos con actividad prebiótica. Revista Mexicana de Ciencias Farmacéuticas, 37, 5-9.

Cardelle-Cobas, A., Corzo, N., Olano, A., Peláez, C., Requena, T., \& Ávila, M. (2011). Galactooligosaccharides derived from lactose and lactulose: influence of structure on Lactobacillus, Streptococcus and Bifidobacterium growth. International Journal of Food Microbiology, 149(1), 81-87. http://dx.doi.org/10.1016/j.ijfoodmicro.2011.05.026. PMid:21700354.

Chantaro, P., Devahastin, S., \& Chiewchan, N. (2008). Production of antioxidant high dietary fiber powder from carrot peels. LWT - Food Science and Technology, 41(10), 1987-1994. http://dx.doi. org/10.1016/j.lwt.2007.11.013.

Chávez-Zepeda, L. P., Cruz, M. G., Díaz-Vela, J., \& Pérez-Chabela, M. L. (2009). Utilización de subproductos agroindustriales como fuente de fibra para productos cárnicos. Nacameh, 3(2), 71-82.

Chetachukwu, A. S., Thongraung, C., \& Yupanqui, C. T. (2019). Development of reduced-fat coconut yoghurt: physicochemical, rheological, microstructural and sensory properties. International Journal of Dairy Technology, 72(4), 524-535. http://dx.doi. org/10.1111/1471-0307.12600.

Cho, W.-Y., Yeon, S.-J., Hong, G.-E., Kim, J.-H., Tsend-Ayush, C., \& Lee, C.-H. (2017). Characteristics of yogurt added green olive powder during storage. Korean Journal for Food Science of Animal Resources, 37(6), 865-872. PMid:29725208.

Clark, R., \& Johnson, S. (2002). Sensory acceptability of foods with added lupin (Lupinus angustifolius) kernel fiber using pre-set 
criteria. Journal of Food Science, 67(1), 356-362. http://dx.doi. org/10.1111/j.1365-2621.2002.tb11410.x.

Coskun, F., \& Karabulut Dirican, L. (2019). Effects of pine honey on the physicochemical, microbiological and sensory properties of probiotic yoghurt. Food Science and Technology (Campinas), 39(Suppl. 2), 616-625. http://dx.doi.org/10.1590/fst.24818.

Costa, G. M., Paula, M. M., Costa, G. N., Esmerino, E. A., Silva, R., Freitas, M. Q., Barão, C. E., Cruz, A. G., \& Pimentel, T. C. (2020). Preferred attribute elicitation methodology compared to conventional descriptive analysis: A study using probiotic yogurt sweetened with xylitol and added with prebiotic components. Journal of Sensory Studies, 35(6), e12602. http://dx.doi.org/10.1111/joss.12602.

Der, G., \& Everitt, B. S. (2008). A handbook of statistical analyses using SAS (3rd ed.). London: Chapman \& Hall/CRC. http://dx.doi. org/10.1201/9781584887850.

Díaz-Jiménez, B., Sosa-Morales, M. E., \& Vélez-Ruíz, J. F. (2004). Efecto de la adición de fibra y la disminución de grasa en las propiedades fisicoquímicas del yogur. Revista Mexicana de Ingeniería Química, 3, 287-305.

do Espírito Santo, A. P., Perego, P., Converti, A., \& Oliveira, M. N. (2012). Influence of milk type and addition of passion fruit peel powder on fermentation kinetics, texture profile and bacterial viability in probiotic yoghurts. Lebensmittel-Wissenschaft + Technologie, 47(2), 393-399. http://dx.doi.org/10.1016/j.lwt.2012.01.038.

Dönmez, Ö., Mogol, B. A., \& Gökmen, V. (2017). Syneresis and rheological behaviors of set yogurt containing green tea and green coffee powders. Journal of Dairy Science, 100(2), 901-907. http:// dx.doi.org/10.3168/jds.2016-11262. PMid:28012628.

Dubois, M., Gilles, K. A., Hamilton, J. K., Rebers, P. A., \& Smith, F. (1956). Colorimetric method for determination of sugars and related substances. Analytical Chemistry, 28(3), 350-356. http://dx.doi. org/10.1021/ac60111a017.

Fazilah, N. F., Ariff, A. B., Khayat, M. E., Rios-Solis, L., \& Halim, M. (2018). Influence of probiotics, prebiotics, synbiotics and bioactive phytochemicals on the formulation of functional yogurt. Journal of Functional Foods, 48, 387-399. http://dx.doi.org/10.1016/j.jff.2018.07.039.

Fernández, M. A., \& Marette, A. (2017). Potential health benefits of combining yogurt and fruits based on their probiotic and prebiotic properties. Advances in Nutrition, 8(1), 155S-164S. http://dx.doi. org/10.3945/an.115.011114. PMid:28096139.

Gandhi, V. P., \& Zhou, Z. (2014). Food demand and the food security challenge with rapid economic growth in the emerging economies of India and China. Food Research International, 63, 108-124. http:// dx.doi.org/10.1016/j.foodres.2014.03.015.

García, C., Bautista, L., Rendueles, M., \& Díaz, M. (2019). A new synbiotic dairy food containing lactobionic acid and Lactobacillus casei. International Journal of Dairy Technology, 72(1), 47-56. http:// dx.doi.org/10.1111/1471-0307.12558.

García-Amezquita, L. E., Tejada-Ortigoza, V., Serna-Saldivar, S. O., \& Welti-Chanes, J. (2018). Dietary fiber concentrates from fruit and vegetable by-products: processing, modification, and application as functional ingredients. Food and Bioprocess Technology, 11(8), 1439-1463. http://dx.doi.org/10.1007/s11947-018-2117-2.

Gómez-Gallego, C., Gueimonde, M., \& Salminen, S. (2018). The role of yogurt in food-based dietary guidelines. Nutrition Reviews, 76(Suppl. 1), 29-39. http://dx.doi.org/10.1093/nutrit/nuy059. PMid:30452698.

Huebner, J., Wehling, R. L., \& Hutkins, R. W. (2007). Functional activity of commercial prebiotics. International Dairy Journal, 17(7), 770775. http://dx.doi.org/10.1016/j.idairyj.2006.10.006.
Kantar Worldpanel. (2018). Día de la papa frita: descubre si eres fan. Retrieved from https://www.kantarworldpanel.com/mx/Noticias-/ Da-de-la-papa-frita-Descubre-si-eres-un-fan

Lagrange, V., Whitsett, D., \& Burris, C. (2015). Global market for dairy proteins. Journal of Food Science, 80(Suppl 1), A16-A22. http:// dx.doi.org/10.1111/1750-3841.12801. PMid:25757893.

Manzoor, S., Yusof, Y. A., Chin, N. L., Mohamed, I. S., Tawakkal, A., Fikry, M., \& Chang, L. S. (2019). Quality characteristics and sensory profile of stirred yogurt enriched with papaya peel powder. Pertanika. Journal of Tropical Agricultural Science, 42(2), 519-533.

Marette, A., Picard-Deland, É., \& Fernandez, M. A. (2017). Yogurt: roles in nutrition and impacts on health. Boca Raton: CRC Press.

Moghaddam, S. T., Javadi, A., \& Matin, A. A. (2020). Reduction of bisphenol A by Lactobacillus acidophilus and Lactobacillus plantarum in yoghurt. International Journal of Dairy Technology, 73(4), 737742. http://dx.doi.org/10.1111/1471-0307.12706.

Mohdaly, A. A., Sarhan, M. A., Smetanska, I., \& Mahmoud, A. (2010). Antioxidant properties of various solvent extracts of potato peel, sugar beet pulp and sesame cake. Journal of the Science of Food and Agriculture, 90(2), 218-226. http://dx.doi.org/10.1002/jsfa.3796. PMid:20355034.

O’Rell, K., \& Chandan, R. C. (2013) Yogurt: fruit preparations and flavoring materials. In R. C. Chandan \& A. Kilara (Eds.), Manufacturing yogurt and fermented milks. Ames: John Wiley and Sons. http:// dx.doi.org/10.1002/9781118481301.ch9.

Palafox-Carlos, H., Yahia, E., Islas-Osuna, M. A., Gutiérrez-Martínez, P., Robles-Sánchez, M., \& González-Aguilar, G. A. (2012). Effect of ripeness stage of mango fruit (Mangifera indica L., cv. Ataulfo) on physiological parameters and antioxidant activity. Scientia Horticulturae, 135, 7-13. http://dx.doi.org/10.1016/j.scienta.2011.11.027.

Patil, A. V., \& Bharati, P. (2019). Antioxidant dietary fiber: a healthy functional ingredient. Journal of Pharmaceutical Innovation, 8, 272-275.

Peng, D., Zahid, H. F., Ajlouni, S., Dunshea, F. R., \& Suleria, H. A. R. (2019). LC-ESI-QTOF/MS profiling of australian mango peel by-product polyphenols and their potential antioxidant activities. Process, 7(10), 764. http://dx.doi.org/10.3390/pr7100764.

Pérez-Chabela, M. L., \& Hernández-Alcántara, A. M. (2018). Agroindustrial coproducts as sources of novel functional ingredients. In A. M. Grumezescu \& A. M. Holban (Eds.), Food processing for increased quality and consumption. New York: Academic Press. http://dx.doi. org/10.1016/B978-0-12-811447-6.00008-4.

Rafiq, S., Huma, N., Pasha, I., Sameen, A., Mukhtar, O., \& Khan, M. I. (2016). Chemical composition, nitrogen fractions and amino acids profile of milk from different animal species. Asian-Australasian Journal of Animal Sciences, 29(7), 1022-1028. http://dx.doi.org/10.5713/ ajas.15.0452. PMid:26954163.

Re, R., Pellegrini, N., Proteggente, A., Pannala, A., Yang, C., \& Rice-Evans, C. (1999). Antioxidant activity applying an improved ABTS radical cation decolorization assay. Free Radical Biology \& Medicine, 26(910), 1231-1237. http://dx.doi.org/10.1016/S0891-5849(98)00315-3. PMid:10381194.

Ribeiro, A. S., Silva, M. N., Tagliapietra, B. L., Brum Júnior, B. S., Ugalde, M. L., \& Richards, N. S. P. S. (2019). Development of symbiotic yoghurt and biological evaluation (New Zealand White Rabbits) of its functional properties. Food Science and Technology (Campinas), 39(Suppl. 2), 418-425. http://dx.doi.org/10.1590/fst.20618.

Rojas-Bravo, M., Rojas-Zenteno, E. G., Hernández-Carranza, P., ÁvilaSosa, R., Aguilar-Sánchez, R., Ruiz-López, I. I., \& Ochoa-Velasco, C. E. (2019). A potential application of mango (Mangifera indica L. $\mathrm{cv}$ manila) peel powder to increase the total phenolic compounds 
and antioxidant capacity of edible films and coatings. Food and Bioprocess Technology, 12(9), 1584-1592. http://dx.doi.org/10.1007/ s11947-019-02317-8.

Rojas-Rivas, E., Espinoza-Ortega, A., Martínez-García, C. G., MoctezumaPérez, S., \& Thomé-Ortiz, H. (2018). Exploring the perception of Mexican urban consumers toward functional foods using the Free Word Association technique. Journal of Sensory Studies, 33(5), e12439. http://dx.doi.org/10.1111/joss.12439.

Santos, R. O., Silva, M. V. F., Nascimento, K. O., Batista, A. L. D., Moraes, J., Andrade, M. M., Andrade, L. G. Z. S., Khosravi-Darani, K., Freitas, M. Q., Raices, R. S. L., Silva, M. C., Barbosa Junior, J. L., Barbosa, M. I. M. J., \& Cruz, A. G. (2018). Prebiotic flours in dairy food processing: technological and sensory implications. International Journal of Dairy Technology, 71, 1-10. http://dx.doi. org/10.1111/1471-0307.12394.

Sarfraz, F., Farooq, U., Shafi, A., Hayat, Z., Akram, K., \& Rehman, H.U. (2019). Hypolipidaemic effects of synbiotic yoghurt in rabbits. International Journal of Dairy Technology, 72(4), 545-550. http:// dx.doi.org/10.1111/1471-0307.12618.

Saulnier, D. M., \& Blaut, M. (2015). Prebiotics beyond fibres. In K. Venema \& A. P. do Carmo (Eds.), Probiotics and prebiotics, current research and future trends. Norfolk: Caister Academic Press. http:// dx.doi.org/10.21775/9781910190098.22.

Secretaría de Agricultura, Ganadería, Desarrollo Rural, Pesca y Alimentación - SAGARPA. (2019). Mango mexicano, Planeación Agrícola Nacional 2017-2030. Retrieved from https://www.gob.mx/ cms/uploads/attachment/file/257078/Potencial-Mango.pdf

Sendra, E., Kuri, V., Fernández-López, J., Sayas-Barberá, E., Navarro, C., \& Pérez-Álvarez, J. A. (2010). Viscoelastic properties of orange fiber enriched yogurt as a function of fiber dose, size and thermal treatment. Lebensmittel-Wissenschaft + Technologie, 43(4), 708-714 http://dx.doi.org/10.1016/j.lwt.2009.12.005.

Sharma, S. K., Bansal, S., Mangal, M., Dixit, A. K., Gupta, R. K., \& Mangal, A. K. (2016). Utilization of food processing by-products as dietary, functional, and novel fiber: a review. Critical Reviews in Food Science and Nutrition, 56(10), 1647-1661. http://dx.doi.org/1 0.1080/10408398.2013.794327. PMid:25748244.

Siebert, K. J., Troukhanova, N. V., \& Lynn, P. Y. (1996). Nature of polyphenol-protein interactions. Journal of Agricultural and Food Chemistry, 44(1), 80-85. http://dx.doi.org/10.1021/jf9502459.

Singh, N., \& Rajini, P. S. (2004). Free radical scavenging activity of an aqueous extract of potato peel. Food Chemistry, 85(4), 611-616. http://dx.doi.org/10.1016/j.foodchem.2003.07.003.

Singlenton, V. L., \& Rossi, J. A. (1965). Colorimetry of total phenolics with phosphomolybdic-phosphotungstic acid reagents. American Journal of Enology and Viticulture, 16, 144-158.

Tovar, A. R., \& Herrera, G. (2017). Introduction to the yogurt in nutrition initiative at the first symposium of yogurt in México: the balanced diet initiative. Advances in Nutrition, 8(1), 144S-145S. http://dx.doi. org/10.3945/an.115.011163. PMid:28096137.

Vieira, F. M., Silva, M. A. P., Martins, Y. A. A., Souza, D. G., Lima, M. S., Placido, G. R., \& Caliari, M. (2015). Physicochemical and sensory profile of yogurt added with passion fruit peel flour. African Journal of Biotechnology, 14(2), 149-155. http://dx.doi.org/10.5897/ AJB2014.14208.

Willey, J. M., Sherwood, L. M., \& Woolverton, C. (2008). Microbiología de Prescott, Harley y Klein (7th ed.). Mexico City: McGraw-Hill. 